\title{
Effect of Dietary Incorporation of Aniseed (Pimpinella anisum) and Ginger (Zingiber officinale) Rhizome Powder as Feed Additive on Growth Performance and Nutrient Utilization in Broiler Chickens
}

\author{
Tushar Gupta*, D.P. Tiwari, K.P. Narayana and B.C. Mondal \\ Department of Animal Nutrition, College of Veterinary and Animal Sciences, G. B. Pant University of Agriculture and \\ Technology, Pantnagar-Uttarakhand, INDIA \\ "Corresponding author: T Gupta; E-mail: tushargupta633@gmail.com
}

Received: 14 Oct., 2019

Revised: 20 Nov., 2019

Accepted: 24 Nov., 2019

\begin{abstract}
A feeding trial was conducted to discern the effect of dietary incorporation of aniseed and ginger rhizome powder on growth performance and nutrient utilization in commercial broiler chickens. A total of 120, day-old broiler chicks were divided randomly into 4 treatment groups with 3 replicates each i.e. 10 broiler chicks per replicate. The feeding trial lasted for 42 days viz., A metabolism trial was conducted during the $6^{\text {th }}$ week of feeding trial to know the nutrient utilization. During the starter phase, maximum weight gain was recorded in broiler chicks of treatment group $\mathrm{T}_{3}(827.70 \mathrm{~g})$ fed diet incorporated with $1.0 \%$ ginger rhizome powder followed by treatment groups $\mathrm{T}_{1}, \mathrm{~T}_{2}$ and $\mathrm{T}_{4}$, however, there was no significant difference in body weight gain amongst the different treatment groups. During finisher phase, the average body weight gain was 1313.50, 1365.32, 1308.20 and $1291.36 \mathrm{~g}$ in broiler chicks of treatment groups $\mathrm{T}_{1}, \mathrm{~T}_{2}, \mathrm{~T}_{3}$ and $\mathrm{T}_{4}$, respectively and did not differ significantly among different groups. During entire feeding trial period (0-42 days), incorporation of aniseed and ginger rhizome powder in the basal diets non-significantly improved growth performance in terms of body weight gain, feed conversion ratio and performance index. The average cumulative body weight gain was 2120.57, 2152.75, 2135.90 and $2064.43 \mathrm{~g}$ in broiler chicks of treatment groups $\mathrm{T}_{1}, \mathrm{~T}_{2}$, $\mathrm{T}_{3}$ and $\mathrm{T}_{4}$, respectively and did not differ significantly among different groups. There was no significant difference in nutrient utilization among different treatment groups of broiler chickens.
\end{abstract}

Keywords: Aniseed, Broiler chicks, Ginger rhizome powder, Growth performance, Nutrient utilization

The fast-growing nature of broilers and their short generation interval has been associated with the use of antibiotic growth promoters in animal feeds. However, the use of antibiotics in the diet is restricted because of their residual effect on birds and in turn adverse effect on human health, environmental hazards and subsequent resistance to bacteria (Lee et al., 2004). Now a day's current research is focused to improve feed conversion ratio and growth rate of birds using useful herbs and herbal preparations as an alternative to antibiotics (Bunyapraphatsara, 2007; Manesh, 2012). Aniseed contains trans-anethole, methylchavicol (Estragole), eugenol, psedoisoeugenol, anisaldehyde. Anethole also inhibits growth of mycotoxin produced by Aspergillus species. Anethole, anisaldehyde and myristicin (in aniseed), along with d-carvone (present in $P$. anisum plant), have been found to have mild insecticidal properties (Leung and Foster, 1996). Aniseed has the ability to improve digestive enzymes by enhancing utilization of nutrients, preventing the growth and activity of pathogenic microorganisms. Pharmacological studies were carried out in broilers, and anise oil showed significant antipyretic activities in rats (Afifi et al., 1994). Aniseed is used to treat dyspeptic and catarrh of the respiratory tract, and as mild expectorants. It was also reported that extracts from anise fruits have therapeutic effects on several conditions, such as gynaecological

How to cite this article: Gupta, T., Tiwari, D.P., Narayana, K.P. and Mondal, B.C. (2019). Effect of dietary incorporation of aniseed (Pimpinella anisum) and ginger (Zingiber officinale) rhizome powder as feed additive on growth performance and nutrient utilization in broiler chickens. $J$. Anim. Res., 9(6): 913-917. 
and neurological disorders (Lawless, 1999). The most important phytochemical compounds present in ginger are gingerol, gingerdiol and gingerdione which have the ability to stimulate digestive enzymes for enhancing utilization of nutrients, preventing the growth and activity of pathogenic microorganisms in the gut and possess anti-oxidative activity (Dieumou et al., 2009; Platel and Srinivasan, 2000). It is reported that ginger has lipid-lowering effects, antioxidant and anti-atherosclerotic properties(Shirin and Prakash, 2010). The ginger preserves the lipid-based feeds due to the prevention of auto-oxidation of linoleic acid by gingerol (Kikuzaki and Nakatani, 1993), improves the shelf-life of meat (Ziauddin et al., 1995) and fermented meat sausage (Al-Jalay et al., 1987).

\section{MATERIALS AND METHODS}

A total of 120, day-old commercial broiler chicks (Ven Cobb 400 strain) were procured from R.K. poultry, Bajpur, Uttarakhand and randomly divided into 4 treatment groups with 3 replications having 10 chicks in each in a completely randomized design. The broiler chicks in group $T_{1}$, were fed basal diet (control) whereas chicks of group $T_{2}, T_{3}$ and $T_{4}$ were fed basal diet and incorporated with $1 \%$ aniseed powder, $1 \%$ ginger rhizome powder and $0.5 \%$ aniseed powder plus $0.5 \%$ ginger rhizome powder, respectively. Standard broiler diets for starter (0-3 weeks) and finisher (3-6 weeks) phases of growth were prepared by mixing the different ingredients as shown in Table 1 and provided to all the broiler chicks so as to meet the nutrient requirements as per BIS (2007). The feeds were analyzed for proximate principles as per standard methods (AOAC, 1995). The broiler chicks were raised in a deep litter system under standard management condition and provided ad libitum feed and clean drinking water throughout the trial period.

Body weight of the chicks and feed intake were recorded weekly during the feeding trial and feed conversion ratio (FCR) and performance index were calculated. During the $6^{\text {th }}$ weeks of the experiment, a metabolism trial following standard procedure was conducted for three days 2 chicks from each replicate in each treatment to know the nutrients utilization. The experimental data obtained during the study were analyzed statistically (Snedecor and Cochran, 1994).

\section{RESULT AND DISCUSSION}

The chemical composition of broilers starter and finisher diets are presented in Table 1. The growth performance of broiler chicks fed experimental diet is presented in Table 2. During the starter phase (0-21 days) body weight gain, feed intake, feed conversion ratio and performance index did not differ significantly among different treatment groups of broiler chickens due to dietary incorporation of aniseed and ginger rhizome powder.

Table 1: Ingredient and chemical composition (\%) of basal diet of broiler starter and finisher diets

\begin{tabular}{ccc}
\hline Ingredients & $\begin{array}{c}\text { Broiler starter } \\
(\mathbf{0}-\mathbf{3} \text { weeks })\end{array}$ & $\begin{array}{c}\text { Broiler finisher } \\
\text { (3- - w weeks) }\end{array}$ \\
\hline Maize & 53.00 & 56.00 \\
Deoiled soyabean meal & 36.00 & 32.00 \\
Vegetable oil & 1.00 & 2.00 \\
Rice polish & 3.55 & 3.55 \\
Groundnut cake & 3.00 & 3.00 \\
Lysine & 0.20 & 0.20 \\
DL-methionine & 0.30 & 0.30 \\
Dicalcium phosphate & 1.50 & 1.50 \\
Trace mineral mixture & 0.50 & 0.50 \\
Common salt & 0.40 & 0.40 \\
Vitamin premix & 0.35 & 0.35 \\
Coccidiostat & 0.05 & 0.05 \\
Hepatocare & 0.10 & 0.10 \\
Choline chloride & 0.05 & 0.05 \\
\hline Chemical Composition & & \\
\hline Dry matter & 94.52 & 93.20 \\
Crude protein & 22.17 & 20.21 \\
Ether extract & 5.50 & 5.00 \\
Crude fibre & 4.40 & 4.30 \\
Ash & 6.20 & 7.70 \\
Nitrogen-free extract & 61.73 & 62.79 \\
\hline
\end{tabular}

The results of present study corroborated with the finding of Yazdi et al. (2014) who did not find any significant effect on weight gain and feed conversion ratio of broilers due to incorporation of aniseed powder. Similarly, to the present findings, Barazesh et al. (2013) also showed that addition of ginger powder as feed additives in diet of broilers did not affect growth performance. During the finisher phase (21-42 days) body weight gain, feed intake, feed conversion ratio and performance index (Table 2) did not differ significantly among different treatment groups of broiler chickens due to dietary inclusion of aniseed and ginger rhizome powder. 
Table 2: Average cumulative growth performance of broiler chicks fed diets incorporated with aniseed and ginger rhizome powder

\begin{tabular}{|c|c|c|c|c|}
\hline \multirow{2}{*}{ Parameters } & \multicolumn{4}{|c|}{ Treatments/ Groups } \\
\hline & $T_{1}$ & $T_{2}$ & $T_{3}$ & $\mathbf{T}_{4}$ \\
\hline \multicolumn{5}{|l|}{$0-21$ days } \\
\hline Initial body weight (g) & $41.33 \pm 1.45$ & $40.17 \pm 0.60$ & $42.50 \pm 0.76$ & $42.33 \pm 3.47$ \\
\hline Body weight (g) & $848.40 \pm 27.78$ & $827.60 \pm 7.85$ & $870.20 \pm 7.52$ & $815.40 \pm 10.76$ \\
\hline Weight gain (g) & $807.07 \pm 28.06$ & $787.43 \pm 8.38$ & $827.70 \pm 8.23$ & $773.07 \pm 13.52$ \\
\hline Feed intake (g) & $1114.33 \pm 20.35$ & $1095.83 \pm 22.19$ & $1123.83 \pm 11.49$ & $1079.37 \pm 18.7$ \\
\hline Feed conversion ratio & $1.38 \pm 0.03$ & $1.39 \pm 0.01$ & $1.36 \pm 0.02$ & $1.40 \pm 0.03$ \\
\hline Performance index & $584.95 \pm 30.67$ & $565.93 \pm 15.50$ & $609.75 \pm 11.42$ & $554.06 \pm 20.04$ \\
\hline Feed cost/ kg weight gain (₹) & $48.25 \pm 0.94$ & $50.38 \pm 0.49$ & $49.62 \pm 0.56$ & $50.83 \pm 0.92$ \\
\hline \multicolumn{5}{|l|}{ 21-42 days } \\
\hline Body weight (g) & $2161.90 \pm 17.09$ & $2192.92 \pm 11.32$ & $2178.40 \pm 37.35$ & $2106.76 \pm 14.65$ \\
\hline Weight gain (g) & $1313.50 \pm 13.99$ & $1365.32 \pm 15.23$ & $1308.20 \pm 40.93$ & $1291.36 \pm 20.33$ \\
\hline Feed intake $(\mathrm{g})$ & $2834.58 \pm 136.59$ & $2743.92 \pm 49.78$ & $2616.20 \pm 69.49$ & $2619.13 \pm 54.84$ \\
\hline Feed conversion ratio & $2.16 \pm 0.08$ & $2.01 \pm 0.01$ & $2.00 \pm 0.02$ & $2.03 \pm 0.03$ \\
\hline Performance index & $610.34 \pm 16.20$ & $679.42 \pm 3.05$ & $654.29 \pm 24.97$ & $637.03 \pm 15.07$ \\
\hline Feed cost/ kg weight gain (₹) & $75.00 \pm 2.80$ & $75.17 \pm 0.53$ & $76.16 \pm 0.81$ & $76.54 \pm 1.24$ \\
\hline \multicolumn{5}{|l|}{ 0-42 days } \\
\hline Body weight (g) & $2161.90 \pm 17.09$ & $2192.92 \pm 11.32$ & $2178.40 \pm 37.35$ & $2106.76 \pm 14.65$ \\
\hline Weight gain $(\mathrm{g})$ & $2120.57 \pm 17.93$ & $2152.75 \pm 10.93$ & $2135.90 \pm 37.34$ & $2064.43 \pm 16.53$ \\
\hline Feed intake $(\mathrm{g})$ & $3948.92 \pm 127.09$ & $3807.30 \pm 8.81$ & $3740.03 \pm 79.20$ & $3725.10 \pm 28.81$ \\
\hline Feed conversion ratio & $1.86 \pm 0.07$ & $1.77 \pm 0.01$ & $1.75 \pm 0.01$ & $1.80 \pm 0.00$ \\
\hline Performance index & $1141.64 \pm 45.67$ & $1217.24 \pm 9.75$ & $1219.87 \pm 18.26$ & $1144.10 \pm 9.68$ \\
\hline Feed cost/ kg weight gain (₹) & $64.85 \pm 2.35$ & $66.11 \pm 0.30$ & $65.85 \pm 0.36$ & $66.89 \pm 0.45$ \\
\hline
\end{tabular}

Table 3: Nutrient utilization (\%) in broiler chicks during finisher phase fed diets incorporated with aniseed and ginger rhizome powder

\begin{tabular}{ccccc}
\hline Parameters & \multicolumn{5}{c}{ Treatments/ Groups } \\
\cline { 2 - 5 } & $\mathbf{T}_{1}$ & $\mathbf{T}_{2}$ & $\mathbf{T}_{3}$ & $\mathbf{T}_{4}$ \\
\hline Dry matter metabolizability & $74.70 \pm 2.45$ & $74.98 \pm 1.64$ & $75.13 \pm 1.92$ & $75.78 \pm 2.32$ \\
Crude protein metabolizability & $72.53 \pm 2.21$ & $74.61 \pm 2.28$ & $74.73 \pm 1.79$ & $74.92 \pm 1.85$ \\
Ether extract digestibility & $75.13 \pm 2.36$ & $76.69 \pm 2.90$ & $76.40 \pm 2.33$ & $77.20 \pm 2.77$ \\
\hline
\end{tabular}

The overall (0-42 days) cumulative performance of broiler (Table 2) in terms of body weight gains, feed intake, feed conversion ratio and performance index did not differ significantly among different treatment groups of broiler chickens due to dietary inclusion of aniseed and ginger rhizome powder. The present results clearly indicated that dietary aniseed and ginger rhizome powder supplementation in broiler diet had no significant effect on growth performance which were similar with the findings of Doley et al. (2009) and Amad et al. (2011) who reported that growth performance of broiler was not influenced by inclusion of ginger rhizome powder. Yazdi et al. (2014) reported that growth performance of broiler was not influenced by inclusion of aniseed powder.

Data pertaining to the average nutrient utilization in broiler chicks are presented in Table 3. The nutrient utilization such as dry matter, crude protein and ether extract in broiler during the metabolism trial revealed no significant improvement in broilers of treatment groups as compare to control group. The present results indicated that the utilization of dry matter, crude protein and ether extract were non-significantly improved due to incorporation of 
aniseed and ginger rhizome powder in the diet of broiler chicks which might be due to fact that the phytochemicals present in aniseed and ginger rhizome stimulate the secretion and activity of digestive enzymes (Zhao et al., 2011; Zhang et al., 2009; Herwati, 2010).

Average feed cost per kg weight gain of broilers given different treatment diets during 0-21 days (starter phase), 21-42 days (finisher phase) and 0-42 days of whole feeding trial did not differ significantly among the various treatment groups of broilers. The average values of feed cost for per $\mathrm{kg}$ weight gain of broilers fed different treatment diets during overall experimental period (0-42 days) were ₹ $64.85,64.11,65.85$ and 66.89 in treatments $\mathrm{T}_{1}, \mathrm{~T}_{2}, \mathrm{~T} 3$ and $\mathrm{T}_{4}$, respectively. The highest feed cost per $\mathrm{kg}$ live weight gain was observed in treatment group $\mathrm{T}_{4}$ supplemented with aniseed powder plus ginger rhizome powder followed by T2 supplemented with aniseed powder, $\mathrm{T}_{3}$ supplemented with ginger rhizome powder and lowest in $\mathrm{T}_{1}$ control, without supplementation of aniseed or ginger rhizome powder.

\section{CONCLUSION}

In the view of the aforesaid findings, it can be concluded that dietary incorporation of aniseed powder or ginger rhizome powder at a level of $1.0 \%$ alone or their combination had no significant effect on growth performance, nutrient utilization.

\section{REFERENCES}

Afifi, N.A., Ramada, A., EL-Kashoury, E.A. and EL-Banna, H.A. 1994. Some pharmacological activities of essential oils of certain umbelliferous fruits. Vet. Med. J. Giza, 42: 85-92.

Al-Jalay, B., Blank, G., McConnel, B. and Al-Khayat, M. 1987. Antioxidant activity of selected spices used in fermented meat sausage. J. Food Prot., 50: 25-27.

Amad, A.A., Manner, K., Wendler, K.R., Neumann, K. and Zentek, J. 2011. Effects of a phytogenic feed additive on growth performance and ileal nutrient digestibility in broiler chickens. J. Poult. Sci. 90(12): 2811-16.

AOAC. 1995.Official Methods of Analysis, $16^{\text {th }}$ Ed. Association of Official Analytical Chemists. Washington, DC, USA.

Barazesh, H., Pour, M.B., Salari, S. and Abadi, T.M. 2013. The effect of ginger powder on performance, carcass characteristics and blood parameters of broilers. Int. J. $A d v$. Bio. and Biomedi. Res. 1(12): 1645-51.
BIS. 2007. Requirement for Chicken Feeds. Bureau of Indian Standards. IS: 1374-2007. Manak Bhavan, 9, Bahadurshah Zafar Marg, New Delhi, India.

Bunyapraphatsara, N. 2007. Utilization of medicinal plants in animal production. $11^{\text {th }}$ International Congress Phytopharmcology. Leiden, The Netherlands.

Dieumou, F.E., Teguia, A., Kuiate, J.R., Tamokou, J.D., Fonge, N.B. and Donogmo, M.C. 2009. Effect of ginger (Zingiber officinale) and garlic (Allium sativum) essential oils on growth performance and gut microbial population of broiler chicks. Livest. Res. Rural Dev., 21(8): 21-33.

Doley, S., Gupta, J.J. and Reddy, P. B.2009. Effect of supplementation of ginger, garlic and turmeric in broiler chicken. Indian Vet. J., 86(6): 644-45.

Herwati. 2010. The effect of feeding red ginger as phytobiotics on body weight gain, feed conversion and internal organs condition of broilers. Int. J. Poultry Sci., 9(10): 963-67.

Kikuzaki, H., Kawasaki, Y. and Nakatani, N. 1994. Structure of antioxidative compounds in ginger, In Food phytochemicals for cancer prevention II. Teas, spices and herbs, ACS symposium series 547. Osawa, M.T. Huang and R.T. Rosen (Eds.), Washington, D C American chemical society, pp. 237 43.

Lawless, J. 1999. The Illustrated Encyclopedia of Essential Oils, The Bridgewater Book Company Ltd., Shaftesbury, pp. 4445.

Lee, K.W., Evarts, H. and Beynen, V. 2004. Essential oils in broilers nutrition. Int. J. Poultry Sci., 3: 738-52.

Leung, A.Y. and Foster, A. 1996. Encyclopedia of common natural ingredients used in food, drugs and cosmetics.

Manesh, M.K. 2012. Influence of poly germander (Teucrium polium) and watercress (Nasturtium officinale) extract on performance, carcass quality and blood metabolites of male broilers. Res. Opinions Ani. Vet. Sci., 2: 69-71.

Platel, K. and Srinivasan, K. 2000. Influence ofdietary spices and their active principles on pancreatic digestive enzymes in Albino rats. Nahrung., 44(1): 42-46.

Shirin, A.P.R. and Prakash, J. 2010. Chemical composition and antioxidant properties of ginger root (Zingiber officinale). $J$. Med. Plants Res., 4(24): 2674- 79.

Snedecor, G.W. and Cochran, W.G. 1994. Statistical Methods. $8^{\text {th }}$ ed., Iowa State University Press, Iowa.

Yazdi, F.F., Ghalamkari, G., Toghiani, M., Modaresi, M. and Landy, N. 2014. Anise seed (Pimpinella anisum L.) as an alternative to antibiotic growth promoters on performance, carcass traits and immune responses in broiler chicks. Asian Pacific J. Trop. Dis., 4(6): 447-51.

Zhang, G.F., Yang, Z.B., Wang, Y., Yang, W.R., Jiang, S.Z. and Gai, G.S. 2009. Effect of ginger root (Zingiber officinale) 
processed to different particle sizes on growth performance, antioxidant status and serum metabolites of broiler chickens. J. Poultry Sci., 88: 2159-66.

Zhao, X.Z., Yang, B., Yang, W.R., Wang, Y., Jiang, S.Z. and Zhang, G.G. 2011. Effects of ginger root (Zingiber officinale) on laying performance and antioxidant status of laying hens and on dietary oxidation stability. J. Poult. Sci., 90(8): 172027.
Ziauddin, K.S., Rao, D.N. and Amla, B.L. 1995. Effect of lactic acid, ginger extract and sodium chloride on quality and shelf life of refrigerated buffalo meat. J. Food Sci. Tech., Mysore, 32(2): 126-28. 
